\title{
Desulfitobacterium aromaticivorans sp. nov. and Geobacter toluenoxydans sp. nov., iron-reducing bacteria capable of anaerobic degradation of monoaromatic hydrocarbons
}

Correspondence

Rainer U. Meckenstock rainer.meckenstock@helmholtzmuenchen.de

\author{
Umakanth Kunapuli, ${ }^{1}$ Michael K. Jahn, ${ }^{1}$ Tillmann Lueders, ${ }^{1}$ \\ Roland Geyer, ${ }^{2}+$ Hermann J. Heipieper ${ }^{3}$ and Rainer U. Meckenstock ${ }^{1}$ \\ ${ }^{1}$ Institute of Groundwater Ecology, Helmholtz Zentrum München - German Research Center for \\ Environmental Health, Ingolstädter Landstraße 1, D-85764 Neuherberg, Germany \\ ${ }^{2}$ Department of Environmental Microbiology, Helmholtz Center for Environmental Research - UFZ, \\ Permoserstraße 15, D-04318 Leipzig, Germany \\ ${ }^{3}$ Department of Bioremediation, Helmholtz Center for Environmental Research - UFZ, \\ Permoserstraße 15, D-04318 Leipzig, Germany
}

\section{INTRODUCTION}

Iron reduction by dissimilatory iron-reducing microbes plays an important role as the terminal electron-accepting process in subsurface sedimentary environments (Thamdrup, 2000) and also constitutes a key process in contaminant degradation in polluted groundwater systems,

tPresent address: LC-MS Support, Applera Europe B.V., Rotkreuz, Switzerland.

Abbreviation: FAME, fatty acid methyl ester.

The GenBank/EMBL/DDBJ accession numbers for the 16S rRNA gene sequences of strains $\mathrm{UKTL}^{\top}$ and $\mathrm{TMJ}^{\top}$ are EU711071 and EU711072.

Electron micrographs of cells of strains $\mathrm{TMJ}^{\top}$ and $\mathrm{UKTL}^{\top}$ and detailed comparisons of their properties with their closest relatives are available as supplementary material with the online version of this paper. landfill leachates and anoxic sediments (Anderson et al., 1998; Christensen et al., 2001; Lovley \& Phillips, 1986). The earliest studies on bacterial iron reduction were performed with a facultatively fermenting bacterium of the genus Bacillus (Roberts, 1947). Later, a non-fermentative, ironreducing pseudomonad that oxidized $\mathrm{H}_{2}$ with $\mathrm{Fe}(\mathrm{III})$ was isolated (Balashova \& Zavarzin, 1979) and reports of a number of phylogenetically diverse dissimilatory ironreducing bacteria and archaea have followed (Weber et al., 2006). In particular, isolates from freshwater sediments have been affiliated to the deltaproteobacterial family Geobacteraceae (Lonergan et al., 1996), with the first species described being Geobacter metallireducens (Lovley et al., 1993). Besides these typical iron reducers, a potential for iron reduction has also been described for several sulfatereducing micro-organisms and methanogens, or by indirect reduction through sulfur cycling (Bond \& 
Lovley, 2002; Coleman et al., 1993; Straub \& Schink, 2004). Methanogens, however, could not couple iron reduction to growth.

Dissimilatory iron-reducing micro-organisms are important for the degradation of monoaromatic hydrocarbons, polycyclic aromatic hydrocarbons and chlorinated compounds (Anderson \& Lovley, 1999; Kunapuli et al., 2007; Sung et al., 2006), with members of the Geobacteraceae identified as very prominent microbes in environmental communities (Cummings et al., 2003; Lin et al., 2005; Rooney-Varga et al., 1999; Sung et al., 2006). Nevertheless, only two species of the genus Geobacter are available in pure culture to date that degrade aromatic hydrocarbons coupled to iron reduction, G. metallireducens and Geobacter grbiciae (Coates et al., 2001; Lovley et al., 1993). This limited number of isolates certainly does not reflect the significance of iron-reducing micro-organisms involved in aromatic hydrocarbon degradation in the environment.

Thus, in this study, for a better understanding of the diversity and physiology of microbes involved in these processes, we enriched and isolated further iron reducers capable of oxidizing aromatic hydrocarbons from different contaminated groundwater sediments. We describe two novel strains, $\mathrm{TMJ}^{\mathrm{T}}$ and $\mathrm{UKTL}^{\mathrm{T}}$, which are phylogenetically and metabolically distinct from available pure cultures. As for the species mentioned above, strain $\mathrm{TMJ}^{\mathrm{T}}$ is also affiliated to the genus Geobacter. For $\mathrm{UKTL}^{\mathrm{T}}$, however, we report here on the first Gram-stainpositive, spore-forming iron-reducer isolated in pure culture that is capable of utilizing aromatic hydrocarbons as sole carbon and energy sources.

\section{METHODS}

Isolation and cultivation. Strains $\mathrm{TMJ}^{\mathrm{T}}$ and $\mathrm{UKTL}^{\mathrm{T}}$ were enriched and isolated in serial liquid dilution-to-extinction cultures with toluene as carbon and energy source and ferrihydrite as the electron acceptor in the presence of Amberlite XAD-7 (Morasch et al., 2000). $\mathrm{XAD}-7$ binds aromatic hydrocarbons strongly and was used to maintain toluene in the medium at a constantly low equilibrium concentration to avoid toxicity effects. For the initial enrichments, well sediment from a tar-oil-contaminated site near Stuttgart, Germany (for strain $\mathrm{TMJ}^{\mathrm{T}}$ ), and soil of a former coal-gasification site in Gliwice, Poland (for strain $\mathrm{UKTL}^{\mathrm{T}}$ ), were used as inocula. Strain $\mathrm{UKTL}^{\mathrm{T}}$ was isolated on toluene from an iron-reducing, benzene-degrading enrichment that was adapted to mineralize benzene completely to $\mathrm{CO}_{2}$ (Kunapuli et al., 2007). Sediment $(5 \mathrm{ml})$ was added to $120 \mathrm{ml}$ serum bottles, half-filled with anaerobic bicarbonate-buffered freshwater medium $(\mathrm{pH}$ 7.2-7.4) prepared under an atmosphere of $\mathrm{N}_{2} / \mathrm{CO}_{2}(80: 20, \mathrm{v} / \mathrm{v})$, that were then incubated at $30{ }^{\circ} \mathrm{C}$ (Widdel \& Bak, 1992). The medium was reduced with $1 \mathrm{mM} \mathrm{FeCl}_{2}(10 \mu \mathrm{M}$ sodium sulfate as sulfur source) for the cultivation of strain $\mathrm{TMJ1}^{\mathrm{T}}$ and with $0.5 \mathrm{mM} \mathrm{Na}_{2} \mathrm{~S}$ (no additional sulfur source) for the cultivation of strain $\mathrm{UKTL}^{\mathrm{T}}$. Strictly anaerobic cultivation techniques were utilized. Toluene was injected with a microlitre syringe (Hamilton Co.) through the butyl-rubber stoppers. After ten transfers (10\% inoculum) to fresh medium, the cultures were purified in at least two consecutive liquid dilution series (up to $10^{-6}$ ). The purity of both strains was checked microscopically using a phase-contrast microscope and by growth on alternative substrates such as acetate, lactate, formate, glucose and NB medium.

Growth conditions. Substrate utilization tests with strains $\mathrm{TMJ}^{\mathrm{T}}$ and $\mathrm{UKTL}^{\mathrm{T}}$ were performed in duplicate incubations. Anoxic stock solutions of the substrates were prepared with distilled water, autoclaved and added to the bicarbonate-buffered mineral medium. Pyruvate, lactate and glucose were filter-sterilized. Liquid aromatic compounds were injected directly with a microlitre syringe. Solid substrates were added to the bottles prior to autoclaving and later filled with the freshwater medium. Utilization of individual substrates was monitored as an increase in ferrous iron concentration over time.

Tests for the utilization of different electron acceptors [amorphous $\mathrm{Fe}(\mathrm{OH})_{3}$ as aqueous suspension, powdered $S^{0}$ and aqueous solutions of sodium sulfate, sodium sulfite, sodium thiosulfite, manganese(IV) chloride, sodium fumarate and sodium nitrate] were performed in either duplicate or triplicate incubations. Electron acceptors were autoclaved and added to the bottles from anoxic stock solutions. Utilization of various electron acceptors was monitored as growth via either microscopy, colour change of the added electron acceptor or visual turbidity $\left(\mathrm{OD}_{578}\right)$ and sulfide or ferrous iron production (Cline, 1969; Stookey, 1970). Inocula for substrate utilization tests were taken from cultures grown on toluene as substrate and ferric citrate as electron acceptor.

The temperature optimum for growth was determined in triplicate over the range $16-42{ }^{\circ} \mathrm{C}$ and optimum $\mathrm{pH}$ (pH adjusted with $1 \mathrm{M}$ $\mathrm{HCl}$ or $0.5 \mathrm{M} \mathrm{Na}_{2} \mathrm{CO}_{3}$ ) was determined in duplicate incubations between pH 6.5 and 8.0, with toluene as carbon source. To test the dependency of growth on vitamins, a freshwater mineral medium without vitamins was prepared and growth of the strains was monitored by observing iron reduction in triplicate incubations with toluene and ferric citrate over five consecutive transfers.

Electron recoveries for both strains were calculated from three parallel experiments with cultures grown on toluene-ferric citrate medium in the absence of XAD-7, together with sterile (autoclaved three times over three consecutive days) and culture-unamended controls.

Analytical procedures. Toluene concentrations were determined with GC/MS (Thermo Finnigan GC; $250 \mu$ l headspace sample) with split injection ( $1: 10$ split ratio) using a fused-silica capillary column (DB-5, $30 \mathrm{~m}$ long and $0.25 \mathrm{~mm}$ i.d., $0.25 \mu \mathrm{m}$ film thickness; Agilent). The temperature was held at $40{ }^{\circ} \mathrm{C}$ for $1 \mathrm{~min}$, raised to $200{ }^{\circ} \mathrm{C}$ at $15{ }^{\circ} \mathrm{C}$ $\min ^{-1}$ and then to $300{ }^{\circ} \mathrm{C}$ at $25^{\circ} \mathrm{C} \mathrm{min}{ }^{-1}$ and held there for $1 \mathrm{~min}$. Carrier gas was helium at a flow rate of $1 \mathrm{ml} \mathrm{min}^{-1}$. MS analysis was carried out using a Trace-DSQ MS unit (Thermo Finnigan) in SIM (selective ion monitoring) mode. External standards of toluene were used to calculate concentrations. For the identification of metabolites, culture supernatants were adjusted to $\mathrm{pH}<2$ with $37 \% \mathrm{HCl}$ and intermediates of toluene and $o$-xylene degradation were derivatized (silylation) as described elsewhere (Morasch et al., 2004).

Morphological characteristics. For Gram-staining, both strains were grown on toluene-ferric citrate freshwater medium. $G$. metallireducens DSM $7210^{\mathrm{T}}$ was used as a control for Gram-stainnegative cells and Bacillus subtilis DSM $10^{\mathrm{T}}$ as a control for Gramstain-positive cells. To check for spore formation, cultures were pasteurized at $80{ }^{\circ} \mathrm{C}$ for $10 \mathrm{~min}$ in $20 \mathrm{ml}$ glass tubes sealed with butyl-rubber stoppers. The pasteurized cultures were reinoculated into triplicate bottles containing $50 \mathrm{ml}$ toluene-ferric citrate freshwater medium and incubated at $30{ }^{\circ} \mathrm{C}$. Utilization of the substrates was monitored as an increase in ferrous iron concentration.

For electron microscopy, the samples were washed twice with $1 \times$ PBS and fixed with $2 \mathrm{ml} 5 \%$ glutaraldehyde in PBS (pH 7.4) overnight at $4{ }^{\circ} \mathrm{C}$. The fixed cells were dehydrated through a series of ethanol solutions at increasing concentrations (50, 70, 80, 95 and 
$100 \%$ ethanol). Ethanol was replaced with liquid $\mathrm{CO}_{2}$ and the samples were dried in a critical-point dryer. After drying, the samples were coated with a $5 \mathrm{~nm}$ platinum layer in an Emitech K575X sputter coater (EM technologies) and examined in a scanning electron microscope (JSM 6300F; JEOL).

Total lipid and respiratory quinone analysis. Total lipid analysis was performed using previously reported precautions (White \& Ringelberg, 1998). Total lipids were extracted from lyophilized cells with the one-phase chloroform/methanol buffer system (Bligh \& Dyer, 1959). Medium samples without lyophilized cells served as control blanks. After overnight extraction, equal volumes of chloroform and nanopure water were added to the extract, resulting in a two-phase system. The lower, organic phase (containing lipids) was collected and total lipids were fractionated by silicic acid column chromatography into neutral lipids, glycolipids and polar lipids. Lipopolysaccharide (LPS) hydroxy fatty acids were recovered from the upper aqueous phase of the Bligh and Dyer extraction separately and concentrated with a multi-channel evaporator (Büchi Syncore Polyvap). The acyl chains of polar lipids or LPS were transesterified to the fatty acid methyl esters (FAMEs) by a mild alkaline methanolysis

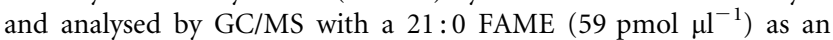
internal standard (Curtis et al., 2006; Guckert et al., 1985).

The MIDI extraction and derivatization procedure included acid hydrolysis (cleaves ester bonds of acyl chains or vinylether bonds of plasmalogens) and derivatization to methyl esters or dimethylacetals, respectively, followed by clean-up steps. Samples were concentrated under nitrogen and resolved in hexane, containing the internal standard.

Determination of the fatty acid composition. Samples containing FAMEs were analysed by GC on an Agilent $6890 \mathrm{~N}$ gas chromatograph with an FID detector. The capillary column was a CP-Sil 88 (Varian Inc.), $50 \mathrm{~m}$ in length with an internal diameter of $0.25 \mathrm{~mm}$. The initial oven temperature was $40{ }^{\circ} \mathrm{C}$ for $2 \mathrm{~min}$ and the final temperature was $220{ }^{\circ} \mathrm{C}$, with a ramp rate of $8{ }^{\circ} \mathrm{C} \min ^{-1}$. The injector was at $240{ }^{\circ} \mathrm{C}$, the flow was in splitless mode and helium was used as carrier gas. The detector was set at $270{ }^{\circ} \mathrm{C}$. Peak identification was achieved using a qualitative standard of bacterial FAMEs from Supelco.

Reference strains for fatty acid analysis were purchased from the Deutsche Sammlung für Mikroorganismen und Zellkulturen (DSMZ, Braunschweig, Germany). Geobacter bremensis DSM $12179^{\mathrm{T}}$ and Geobacter chapellei DSM $13688^{\mathrm{T}}$ were grown with Geobacter medium DSM 826. Desulfitobacterium chlororespirans DSM $11544^{\mathrm{T}}$ was grown with Desulfitobacterium hafniense medium (DSM 720) and Desulfosporosinus orientis DSM $765^{\mathrm{T}}$ with Desulfovibrio medium (DSM 63).

For analysis of respiratory quinones, lyophilized samples were extracted with $5 \mathrm{ml}$ pentane by vigorous shaking for $60 \mathrm{~min}$ and five $1 \mathrm{~min}$ bursts of sonication. After centrifugation for $10 \mathrm{~min}$ at 5000 r.p.m., the supernatant was transferred to a fresh vial and evaporated under a gentle stream of nitrogen. Residues were dissolved in $100 \mu \mathrm{l}$ methanol and examined by HPLC/APCI/MS/MS (Geyer et al., 2004) using a more-sensitive hybrid quadrupole-linear ion trap mass spectrometer (4000 QTRAP; Applied Biosystems/MDS Sciex) to monitor 44 different quinones (ubiquinones 6-14, menaquinones 614 , demethylmenaquinones 6-10, thermoplasmamenaquinones, phylloquinones and plastoquinones) with the following HPLC method; a gradient of methanol (solvent A) and tert-methyl butyl ether (TMBE; solvent B) was applied on a DASH-8 column $(20 \times 2.1 \mathrm{~mm}$, $5 \mu \mathrm{m}$; Thermo) at a flow rate of $250 \mu \mathrm{min}^{-1}$ and $15{ }^{\circ} \mathrm{C}$ column temperature. The gradient for solvent A was $0.0-0.2 \mathrm{~min}, 100 \%$; $1.3-$ $5.0 \mathrm{~min}, 20 \%$; $5.3-8.0 \mathrm{~min}, 100 \%$. Aliquots of quinone standards
(Q-6 and MK-4) were used to obtain a calibration curve for ubiquinones and menaquinones prior to sample measurements.

DNA extraction and 16S rRNA gene sequencing. DNA was extracted from harvested $(\sim 0.5 \mathrm{ml})$ cell pellets from toluene/ferric citrate-grown cultures as described previously (Lueders et al., 2004). Full-length 16S rRNA genes were amplified by PCR using primers Ba27f and Ba1492r (Weisburg et al., 1991). The PCR mixture (50 $\mu \mathrm{l}$ ) consisted of $1 \times$ PCR buffer (Fermentas), $1.5 \mathrm{mM} \mathrm{MgCl}_{2}, 10 \mu \mathrm{g}$ BSA, $0.1 \mathrm{mM}$ dNTPs, $0.25 \mu \mathrm{M}$ each primer, $1 \mathrm{U}$ Taq DNA polymerase (Fermentas) and $1 \mu \mathrm{l}$ undiluted or 1/10-diluted DNA extract, depending on yield. The conditions for thermal cycling were initial denaturation at $94{ }^{\circ} \mathrm{C}$ for $3 \mathrm{~min}$ and 28 cycles of $94{ }^{\circ} \mathrm{C}$ for $30 \mathrm{~s}, 52{ }^{\circ} \mathrm{C}$ for $30 \mathrm{~s}$ and $70{ }^{\circ} \mathrm{C}$ for $60 \mathrm{~s}$ followed by a final elongation cycle at $70{ }^{\circ} \mathrm{C}$ for $5 \mathrm{~min}$. Direct sequencing using amplicon primers (Ba27f, Ba519f, Ba1492r) was performed on an ABI 3730 sequencer (Applied Biosystems) using the BigDye Terminator version 3.1 chemistry as specified by the manufacturer. $16 \mathrm{~S}$ rRNA gene sequence reads were assembled manually and quality-controlled using SeqMan II (DNASTAR). Closely related $16 \mathrm{~S}$ rRNA gene sequences were identified using the BLASTN search program (http://ncbi.nlm.nih.gov/blast). For phylogenetic affiliation, sequences were integrated into an ARB database (Ludwig et al., 2004) and aligned using the ARB-EDIT4 alignment editor. A tree showing the phylogenetic affiliation of the two novel isolates was reconstructed using quartet puzzling (Strimmer \& von Haeseler, 1996) as implemented in ARB using 10000 puzzling steps, the TN substitution model and gamma-distributed rate heterogeneities estimated from the dataset. A bacterial $16 \mathrm{~S}$ rRNA base frequency filter implemented in ARB and inferred to optimally reconstruct clostridial phylogeny was used to exclude nucleotide positions with less than $50 \%$ invariance from tree reconstruction. Tree topology and branching order were also verified using maximum-likelihood, maximum-parsimony and neighbour-joining algorithms as implemented in the ARB software package.

Determination of $\mathbf{G}+\mathbf{C}$ content. DNA $G+C$ contents of strains $\mathrm{TMJ}^{\mathrm{T}}$ and $\mathrm{UKTL}^{\mathrm{T}}$ were measured at the DSMZ. Briefly, DNA was extracted from the cell pellet as described by Cashion et al. (1977). The extracted DNA was hydrolysed with P1 nuclease and the nucleotides were dephosphorylated with bovine alkaline phosphatase (Mesbah et al., 1989). The resulting deoxyribonucleosides were analysed by HPLC. DNA from B. subtilis DSM $402(43.518 \mathrm{~mol} \%$ $\mathrm{G}+\mathrm{C})$, Xanthomonas campestris DSM $3586^{\mathrm{T}}(65.069 \mathrm{~mol} \%)$ and Streptomyces violaceoruber DSM 40783 (72.119 mol\%) was used as references. The HPLC system (Shimadzu) consisted of the following modules: LC-20AD solvent delivery module, DGU-3A online degasser, CTO-10AC column oven, SIL-9A automatic sample injector, SPD-6A UV spectrophotometric detector and a C-R4AX Chromatopac integrator. The analytical column was a Vydac 201SP54, $C_{18}, 5 \mu \mathrm{m}(250 \times 4.6 \mathrm{~mm})$, equipped with a Vydac $201 \mathrm{GD} 54 \mathrm{H}$ guard column. The temperature was $45^{\circ} \mathrm{C}$, sample injection volume was $10 \mu \mathrm{l}$ and the solvent was $0.3 \mathrm{M}\left(\mathrm{NH}_{4}\right) \mathrm{H}_{2} \mathrm{PO}_{4} /$ acetonitrile $[40: 1(\mathrm{v} / \mathrm{v}), \mathrm{pH} 4.4]$ at a flow rate of $1.3 \mathrm{ml} \mathrm{min} \mathrm{min}^{-1}$ (adapted from Tamaoka \& Komagata, 1984).

\section{RESULTS}

\section{Morphology and physiology}

Strains $\mathrm{TMJ1}^{\mathrm{T}}$ and $\mathrm{UKTL}^{\mathrm{T}}$ were enriched with toluene as growth substrate and ferrihydrite as the electron acceptor in the presence of Amberlite XAD-7. After several transfers, rapid growth of both enrichments was established, and pure cultures were isolated in liquid dilution series. 
Morphological characteristics of strains $\mathrm{TMJ}^{\mathrm{T}}$ and $\mathrm{UKTL}^{\mathrm{T}}$ are depicted in Supplementary Fig. S1 and further described in detail in Supplementary Tables S1 and S2 (available in IJSEM Online). Strains TMJ1 ${ }^{\mathrm{T}}$ and $\mathrm{UKTL}^{\mathrm{T}}$ utilized a wide range of aromatic compounds with ferric citrate as electron acceptor (Supplementary Tables S1 and S2). When acetate was provided as the electron donor, several electron acceptors were used by both strains. Sulfite, however, was utilized only by $\mathrm{UKTL}^{\mathrm{T}}$ with pyruvate as electron donor (Supplementary Table S2).

\section{Degradation of aromatic compounds}

Electron balances showed that toluene was oxidized completely to $\mathrm{CO}_{2}$ with an electron recovery of $93 \pm 1 \%$ for strain $\mathrm{UKTL}^{\mathrm{T}}$ (Fig. 1a) and $99 \pm 14 \%$ for strain TMJ1 ${ }^{\mathrm{T}}$ (Fig. 1b), assuming that the electrons from $1 \mathrm{mmol}$ toluene will reduce $36 \mathrm{mmol}$ iron(III). No decrease in the toluene concentration or increase in the ferrous iron concentration was observed in sterilized or culture-unamended controls (not shown). When the culture supernatants were examined for possible intermediates of toluene and $o$ xylene degradation, benzylsuccinate was identified in the culture supernatants of both strains grown on toluene and methylbenzylsuccinate in the supernatant of an $o$-xylenegrown culture of strain $\mathrm{UKTL}^{\mathrm{T}}$ by GC/MS (not shown). Similarly, hydroxybenzoate was identified by GC/MS in the culture supernatants of both strains grown on $p$-cresol and in the supernatant of an $m$-cresol-grown culture of strain $\mathrm{TMJ1}^{\mathrm{T}}$ (not shown).

\section{Phylogenetic analysis}

Phylogenetic analysis of $16 \mathrm{~S}$ rRNA gene sequences revealed that strain $\mathrm{TMJ} 1^{\mathrm{T}}$ belongs to the genus Geobacter within the Geobacteraceae (Deltaproteobacteria; Fig. 2). The closest relatives of strain $\mathrm{TMJ}^{\mathrm{T}}$ were 'Geobacter humireducens' JW3, with a sequence similarity of $96 \%$, and G. bremensis Dfr $1^{\mathrm{T}}$, with a sequence similarity of $95.4 \%$.

BLAST search results with the $16 \mathrm{~S}$ rRNA gene sequence of strain $\mathrm{UKTL}^{\mathrm{T}}$ revealed it as a member of the low-G $+\mathrm{C}-$ content Gram-positive Clostridia within the family Peptococcaceae, with the closest relatives being the type strains of Desulfosporosinus orientis and Desulfitobacterium chlororespirans, with sequence similarity of 94.2 and $94 \%$, respectively. Based on the tree topology (Fig. 2), strain $\mathrm{TMJ} 1^{\mathrm{T}}$ was clearly affiliated to the genus Geobacter, while strain $\mathrm{UKTL}^{\mathrm{T}}$ was less directly affiliated to members of the genera Desulfitobacterium (nearest relatives Desulfitobacterium chlororespirans and Desulfitobacterium dehalogenans) and Desulfosporosinus (closest relative Desulfosporosinus orientis). The apparent closer affiliation of $\mathrm{UKTL}^{\mathrm{T}}$ to members of the genus Desulfitobacterium indicated in the Puzzle dendrogram in Fig. 2 was not reproduced consistently by the maximum-likelihood, maximum-parsimony and distance-matrix treeing methods applied. This is also reflected by the fact that
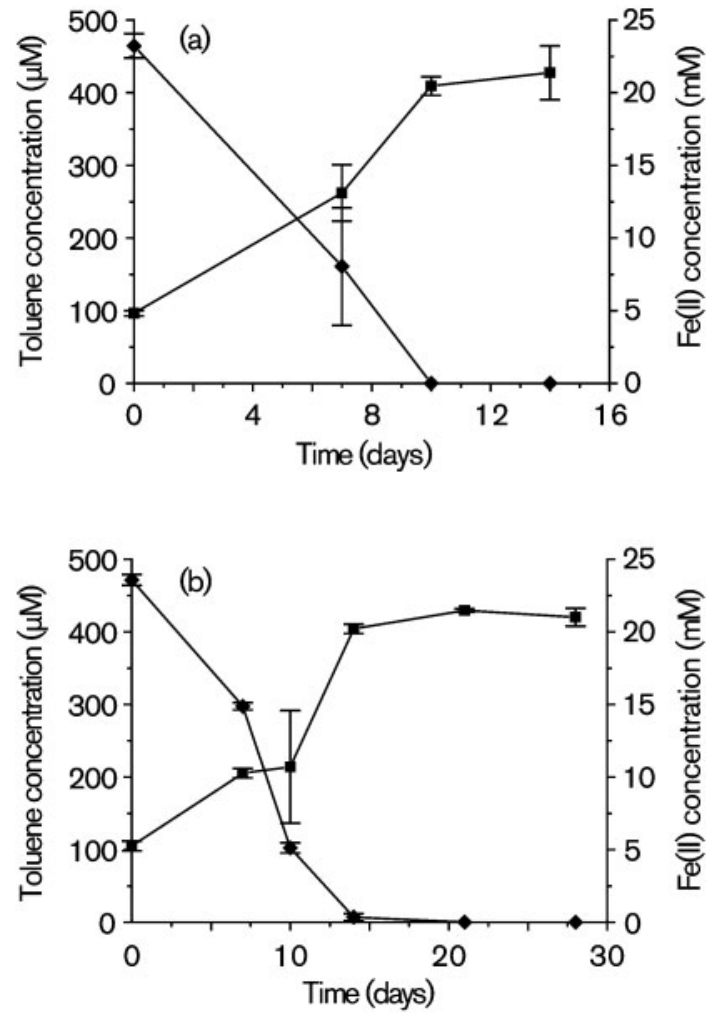

Fig. 1. Electron balance experiments with strain $\mathrm{TMJ}^{\top}{ }^{\top}$ (a) and strain $\mathrm{UKTL}^{\top}$ (b) in batch culture with toluene as growth substrate and ferric citrate as electron acceptor. Concentrations of toluene (diamonds) and ferrous iron (squares) were monitored over time. Error bars represent standard deviations of three parallel incubations.

sequence similarity to the more deeply branching Desulfitobacterium metallireducens $853-15 \mathrm{~A}^{\mathrm{T}}$ was only $93.5 \%$, which is even less than the similarity of $94.2 \%$ to Desulfosporosinus orientis DSM $765^{\mathrm{T}}$.

\section{DISCUSSION}

Here, two novel iron-reducing bacterial strains are described that degrade the monoaromatic hydrocarbons toluene (strains $\mathrm{TMJ} 1^{\mathrm{T}}$ and $\mathrm{UKTL}^{\mathrm{T}}$ ) and $o$-xylene (strain $\mathrm{UKTL}^{\mathrm{T}}$ only). Analysis of $16 \mathrm{~S}$ rRNA gene sequences clearly showed that strains $\mathrm{TMJ}^{\mathrm{T}}$ and $\mathrm{UKTL}^{\mathrm{T}}$ are phylogenetically distinct from known monoaromatic hydrocarbon-degrading isolates. Strain $\mathrm{TMJ}^{\mathrm{T}}$ is closely related to members of the genus Geobacter, while strain $\mathrm{UKTL}^{\mathrm{T}}$ is less directly related to members of the genera Desulfosporosinus and Desulfitobacterium within the Clostridia (Fig. 2).

The closest relatives of strain TMJ1 $1^{\mathrm{T}}$, G. bremensis $\mathrm{Dfr} 1^{\mathrm{T}}$, which was isolated with biologically produced ferrihydrite from a freshwater ditch (Straub \& Buchholz-Cleven, 2001), and 'Geobacter humireducens' JW3, isolated from a 


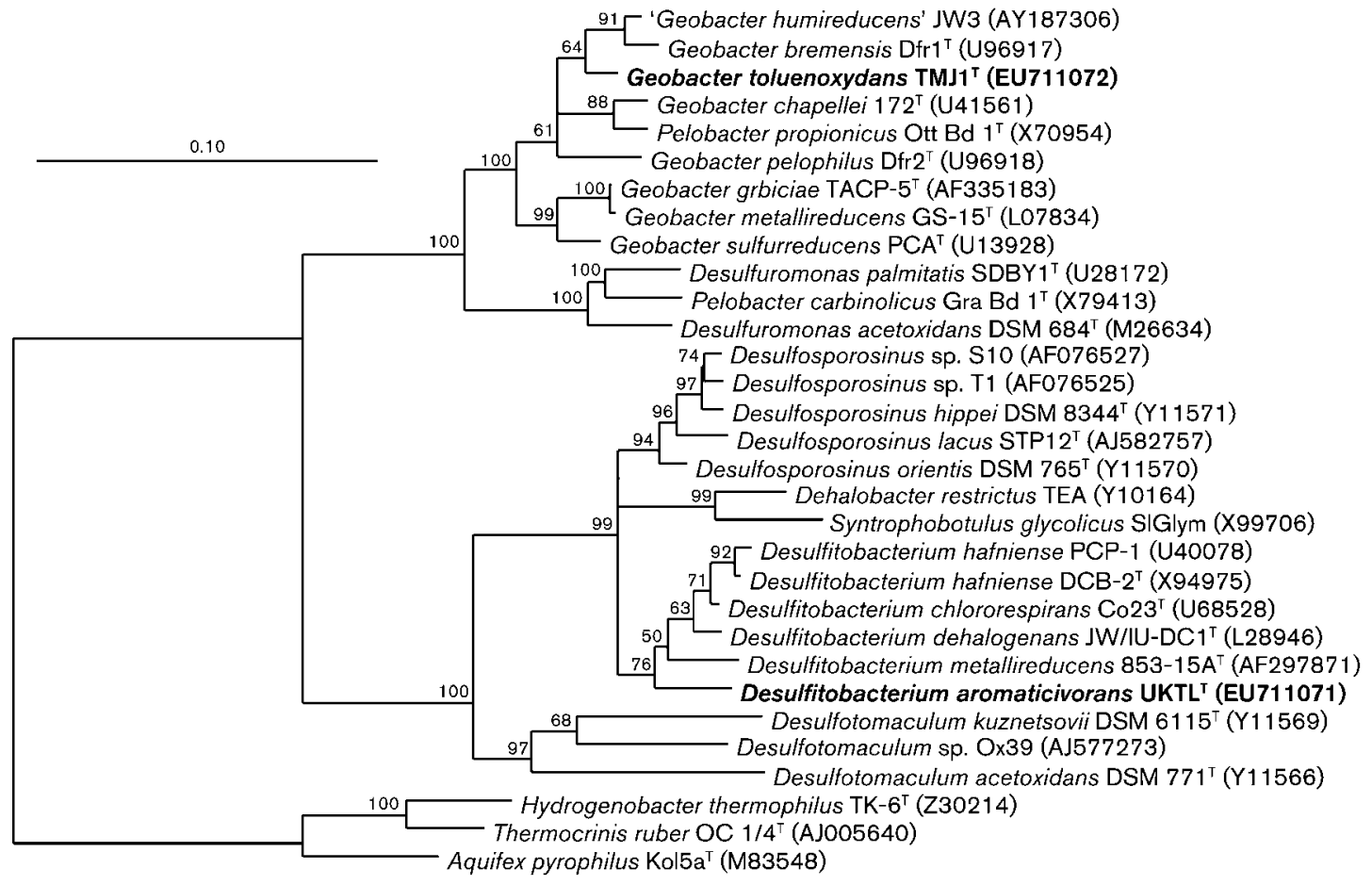

Fig. 2. Phylogenetic tree reconstructed from $16 \mathrm{~S}$ rRNA gene sequences showing the placement of strains $\mathrm{TMJ}^{\top}$ and $U K \mathrm{KL}^{\top}$ among closely related members of the Geobacteraceae and the Peptococcaceae, respectively. GenBank accession numbers are given for each strain. The tree was constructed with the quartet PUZZLE method. Percentages at nodes show branching confidence values deduced from 10000 intermediate trees. Bar, 10\% sequence divergence.

hydrocarbon-contaminated wetland with anthraquinone 2,6-disulfonate as electron acceptor (Coates et al., 1998), were reported to utilize various simple organic acids, but not monoaromatic hydrocarbons or other aromatic compounds except benzoate, as carbon and energy sources (Supplementary Table S1). This clearly distinguishes $\mathrm{TMJ}^{\mathrm{T}}$ from the other two organisms. With respect to utilization of aromatic compounds, strain $\mathrm{TMJ} 1^{\mathrm{T}}$ shows similarities with G. metallireducens and G. grbiciae (Coates et al., 2001; Lovley et al., 1993), the only known ironreducing, aromatic hydrocarbon-degraders of the genus Geobacter, but, based on 16S rRNA gene sequencing, it clusters phylogenetically distinctly from both. This is also supported by a slightly more deeply branching benzylsuccinate synthase alpha-subunit gene previously detected in strain TMJ $1^{\mathrm{T}}$ (Winderl et al., 2007). A novel feature of strain TMJ $1^{\mathrm{T}}$ is its utilization of $m$-cresol as a carbon and energy source.

For more-detailed classification, we compared the substrate utilization of strain $\mathrm{TMJ}^{\mathrm{T}}$ with its closest relative, $G$. bremensis DSM $12179^{\mathrm{T}}$, and with G. chapellei DSM $13688^{\mathrm{T}}$, which clusters a little further away in the 16S rRNA gene phylogenetic tree. The electron donors and acceptors utilized by strain $\mathrm{TMJ} 1^{\mathrm{T}}$, G. bremensis DSM $12179^{\mathrm{T}}$ and G. chapellei DSM $13688^{\mathrm{T}}$ show differences that suggest a physiological distinction (Supplementary Table S1). Utilization of pyruvate, propionate and butyrate as well as ferric citrate by strain $\mathrm{TMJ}^{\mathrm{T}}$ and G. bremensis DSM $12179^{\mathrm{T}}$ distinguish the two from G. chapellei DSM $13688^{\mathrm{T}}$. On the other hand, strains G. bremensis DSM $12179^{\mathrm{T}}$ and G. chapellei DSM $13688^{\mathrm{T}}$ have in common the utilization of lactate as electron donor and $\mathrm{Mn}(\mathrm{IV})$ as electron acceptor, neither of which can be utilized by strain $\mathrm{TMJ} 1^{\mathrm{T}}$.

The genomic DNA G+C content of strain $T M J 1^{\mathrm{T}}$ $(54.4 \mathrm{~mol} \%)$ is comparable to those of its relatives G. bremensis and G. chapellei as well as other members of the genus Geobacter (G. metallireducens GS- $15^{\mathrm{T}}, 56.6 \mathrm{~mol} \%$; Lovley et al., 1993). Whereas menaquinone MK-8 found in strain $\mathrm{TMJ}^{\mathrm{T}}$ is typical of members of the Geobacteraceae such as G. metallireducens and Geobacter sulfurreducens (R. Geyer, unpublished results; Lovley et al., 1993), strain $\mathrm{TMJ} 1^{\mathrm{T}}$ is clearly different in total lipid fatty acid content from G. bremensis DSM $12179^{\mathrm{T}}$ and G. chapellei DSM $13688^{\mathrm{T}}$. Strain $\mathrm{TMJ} 1^{\mathrm{T}}$ contains $15: 0$ anteiso fatty acids, whereas G. bremensis DSM $12179^{\mathrm{T}}$ does not. In contrast to these two other members of the genus Geobacter, strain $\mathrm{TMJ} 1^{\mathrm{T}}$ does not contain the fatty acid $18: 1 \omega 7 c$. These, along with other discriminative characteristics indicated in Supplementary Table S1, prompt us to propose that strain $\mathrm{TMJ} 1^{\mathrm{T}}$ represents a novel geobacterial species, Geobacter toluenoxydans sp. nov.

$16 \mathrm{~S}$ rRNA gene sequencing showed strain $\mathrm{UKTL}^{\mathrm{T}}$ to cluster together with members of the sulfate-reducing bacterial 
genus Desulfosporosinus and members of the genus Desulfitobacterium, known for reductive dehalogenation (Spring \& Rosenzweig, 2006). The closest relatives of strain UKTL $^{\mathrm{T}}$ are Desulfosporosinus orientis, an organic compound-oxidizing sulfate reducer (Stackebrandt et al., 1997), and Desulfitobacterium chlororespirans, known for reductive dehalogenation of chlorophenols (Sanford et al., 1996).

Comparative physiological characteristics revealed important differences between strain $\mathrm{UKTL}^{\mathrm{T}}$ and its nearest relatives (Spring \& Rosenzweig, 2006). Strain $\mathrm{UKTL}^{\mathrm{T}}$ resembles members of the genera Desulfosporosinus and Desulfitobacterium in pyruvate fermentation, utilization of sulfite and thiosulfate and its spore-forming ability but differs in the absence of lactate utilization, sulfate and sulfur reduction and autotrophic growth. The ability of strain $\mathrm{UKTL}^{\mathrm{T}}$ to use acetate as sole electron donor with ferric iron as the electron acceptor (Supplementary Table S2) clearly distinguishes it from other members of the genera Desulfitobacterium and Desulfosporosinus, which do not utilize acetate as a carbon and energy source and perform incomplete oxidation of organic compounds to acetate (Robertson et al., 2001; Spring \& Rosenzweig, 2006; Villemur et al., 2006). Most Desulfosporosinus strains are known to utilize sulfite and thiosulfate in addition to sulfate as electron acceptors, whereas members of the genus Desulfitobacterium were reported to utilize sulfite and thiosulfate but not sulfate, with one known exception (Robertson et al., 2001; Villemur et al., 2006). Strain UKTL $^{\mathrm{T}}$ does not reduce sulfate but utilizes sulfite and thiosulfate as electron acceptors in the presence of pyruvate. Strain $\mathrm{UKTL}^{\mathrm{T}}$ additionally utilizes ferric iron as an electron acceptor, whereas Desulfosporosinus orientis cannot (Stackebrandt et al., 1997). None of the members of the genus Desulfitobacterium isolated so far has been reported to use monoaromatic compounds as carbon and energy sources (Robertson et al., 2001; Villemur et al., 2006). Furthermore, Desulfosporosinus strain Y5, a distant relative of strain $\mathrm{UKTL}^{\mathrm{T}}$, was shown to couple the oxidation of toluene, but not xylene, to the reduction of As(V) (Liu et al., 2004).

Strain $\mathrm{UKTL}^{\mathrm{T}}$ stains Gram-positive, in contrast to its nearest relatives, which stain Gram-negative (Supplementary Table S2). The $\mathrm{G}+\mathrm{C}$ content $(47.4 \mathrm{~mol} \%)$ of strain $\mathrm{UKTL}^{\mathrm{T}}$ is within the range of $45-49 \mathrm{~mol} \%$ reported for the genera Desulfosporosinus and Desulfitobacterium (Spring \& Rosenzweig, 2006). Strain UKTL ${ }^{\mathrm{T}}$ has MK-7 as the major respiratory quinone, which is generally found in the genera Desulfosporosinus and Desulfitobacterium (Imachi et al., 2002; Ramamoorthy et al., 2006; Spring \& Rosenzweig, 2006; Stackebrandt et al., 1997).

Of the 11 specific $16 \mathrm{~S}$ rRNA gene signature nucleotides defined by Stackebrandt et al. (2003) to discriminate between the genera Desulfosporosinus and Desulfitobacterium, strain UKTL $^{\mathrm{T}}$ shares three signatures with the former and six with the latter. The two remaining signature positions are distinct from both (not shown). This substantiates the classification of strain $\mathrm{UKTL}^{\mathrm{T}}$ within a novel species in this phylogenetic neighbourhood. In summary, the large phylogenetic and physiological differences between members of the genera Desulfosporosinus and Desulfitobacterium and the new ironreducing isolate $\mathrm{UKTL}^{\mathrm{T}}$ allow strain $\mathrm{UKTL}^{\mathrm{T}}$ to be classified within a separate species of the genus Desulfitobacterium (Stackebrandt et al., 1997; Villemur et al., 2006).

The findings of benzylsuccinate and methylbenzylsuccinate as major intermediates in toluene- and $o$-xylene-grown cultures of strains $\mathrm{TMJ1}^{\mathrm{T}}$ and $\mathrm{UKTL}^{\mathrm{T}}$ indicated that degradation of toluene and $o$-xylene proceeds via fumarate addition. The benzylsuccinate synthase pathway has been intensively studied and elucidated for Thauera and Azoarcus species (Beller \& Spormann, 1997; Biegert et al., 1996; Leuthner et al., 1998). The benzylsuccinate synthase pathway has been found in every anaerobic, toluene-degrading micro-organism investigated to date (Chakraborty \& Coates, 2004), and bssA genes coding for the alpha subunit of the benzylsuccinate synthase have been established as an environmental marker gene for hydrocarbon degraders (Winderl et al., 2007). The same authors also reported a clearly geobacterial $b s s A$ gene for strain $\mathrm{TMJ}^{\mathrm{T}}{ }^{\mathrm{T}}$, but no homologue has been detected to date in strain $\mathrm{UKTL}^{\mathrm{T}}$. Activation by benzylsuccinate synthase is not only observed in aromatic hydrocarbon-degrading pure-cultured proteobacteria, but was also observed in the spore-forming, Grampositive Desulfotomaculum sp. OX39, which is able to degrade several monoaromatic hydrocarbons (Morasch et al., 2004). Following Desulfotomaculum sp. OX39 and Desulfosporosinus sp. strain Y5, strain $\mathrm{UKTL}^{\mathrm{T}}$ is the third pure culture of a non-proteobacterial isolate capable of degrading aromatic hydrocarbons.

Enrichment and isolation of strain $\mathrm{TMJ} 1^{\mathrm{T}}$ with ferric iron as the electron acceptor from a tar-oil-contaminated site with aromatic non-aqueous-phase liquids (NAPLs) (Zamfirescu \& Grathwohl, 2001) further supports the importance of Geobacter species in natural attenuation of aromatic hydrocarbons. Members of this genus have been observed to be dominant at several sites contaminated with organic compounds (Lovley \& Anderson, 2000). Moreover, clostridia of the genera Desulfosporosinus and Desulfitobacterium, family Peptococcaceae, have also often been isolated from sites contaminated with BTEX (benzene, toluene, ethylbenzene and xylenes) and chlorinated hydrocarbons. Several of these species were reported to be capable of dissimilatory ferric iron reduction, although they are classically considered to be involved in sulfate reduction or dehalogenation (Robertson et al., 2000; Villemur et al., 2006). Recently, asyet uncultured spore-forming members of the Peptococcaceae in a benzene-degrading enrichment culture were reported to utilize ferric iron as an electron acceptor (Kunapuli et al., 2007). Furthermore, two 16S rRNA clones from an ironreducing enrichment utilizing structural ferric iron in smectite with acetate as carbon source were reported to be closely related to Desulfitobacterium chlororespirans (Kostka et al., 2002). These findings further support the 
almost-overlooked environmental importance of members of the Peptococcaceae in dissimilatory iron reduction in subsurface environments (Kunapuli et al., 2007; Zavarzina et al., 2007). The isolation of strains $\mathrm{TMJ}^{\mathrm{T}}$ and $\mathrm{UKTL}^{\mathrm{T}}$ also indicates that a wider range of phylogenetically diverse micro-organisms within and outside the Proteobacteria are responsible for degradation of aromatic hydrocarbons with ferric iron as the terminal electron acceptor and that ironreducing micro-organisms can also oxidize monoaromatic compounds other than toluene.

\section{Description of Geobacter toluenoxydans sp. nov.}

Geobacter toluenoxydans [to.lu.e.nox'y.dans. N.L. n. toluenum toluene; N.L. v. oxydo (from Gr. adj. oxus sharp, acid) to oxidize; N.L. part. adj. toluenoxydans oxidizing toluene].

Gram-stain-negative, non-spore-forming, non-motile, straight rods, $2.1-3.8 \mu \mathrm{m}$ long and $0.4 \mu \mathrm{m}$ wide. Obligate anaerobe. Utilizes ferrihydrite, ferric citrate and fumarate as electron acceptors with acetate as electron donor. Does not reduce $M n(I V)$, nitrate, sulfate, sulfite, thiosulfate or sulfur. Electron donors used include toluene, benzyl alcohol, benzaldehyde, phenol, $m$-cresol, $p$-cresol, acetate, butyrate, formate, propionate, pyruvate and benzoate. Does not utilize fumarate, lactate, malate, succinate or $o$ cresol. $\mathrm{pH}$ range for growth is $\mathrm{pH}$ 6.6-7.5 (optimum $\mathrm{pH}$ 6.6-7.0). Optimum growth temperature is $25-32{ }^{\circ} \mathrm{C}$. Contains 15:0 anteiso but not $18: 1 \omega 7 c$ fatty acids. Characteristics useful to differentiate the type strain from other members of the genus Geobacter are depicted in Table 1 . The $\mathrm{G}+\mathrm{C}$ content of the type strain is $54.4 \mathrm{~mol} \%$.

The type strain, $\mathrm{TMJ}^{\mathrm{T}}\left(=\mathrm{DSM} 19350^{\mathrm{T}}=\mathrm{JCM} 15764^{\mathrm{T}}\right)$, was isolated from sludge of a monitoring well at a tar-oilcontaminated aquifer near Stuttgart, Germany.

\section{Description of Desulfitobacterium aromaticivorans sp. nov.}

Desulfitobacterium aromaticivorans [ar.o.ma.ti'ci.vo' rans. L. adj. aromaticus aromatic, fragrant; L. part. adj. vorans devouring; N.L. part. adj. aromaticivorans devouring aromatic (compounds)].

Table 1. Characteristics useful for differentiating strain $\mathrm{TMJ} 1^{\top}$ from closely related members of the genus Geobacter

Taxa: 1, strain TMJ1 ${ }^{\mathrm{T}}$ (data from this study); 2, G. bremensis (Straub et al., 1998; Straub \& Buchholz-Cleven, 2001); 3, G. chapellei (Coates et al., 2001); 4, G. metallireducens (Lovley et al., 1993); 5, G. sulfurreducens (Caccavo et al., 1994); 6, G. pelophilus (Straub \& Buchholz-Cleven, 2001); 7, G. grbiciae (Coates et al., 2001); 8, G. argillaceus (Shelobolina et al., 2007); 9, G. pickeringii (Shelobolina et al., 2007); 10, G. hydrogenophilus (Coates et al., 2001); 11, G. bemidjiensis (Nevin et al., 2005); 12, G. psychrophilus (Nevin et al., 2005); 13, G. uraniireducens (Shelobolina et al., 2008); 14, G. lovleyi (Sung et al., 2006). Unless indicated, data were determined in the studies listed above using identical methods. Characteristics in bold differentiate strain $\mathrm{TMJ}^{\mathrm{T}}$ from all other tested members of the genus Geobacter. +, Utilized; -, not utilized; U, utilization but no growth; UFE, utilization not coupled to iron reduction; NR, not reported in the original literature; tr, present at less than $1 \%$ of total fatty acids.

\begin{tabular}{|c|c|c|c|c|c|c|c|c|c|c|c|c|c|c|}
\hline Characteristic & 1 & 2 & 3 & 4 & 5 & 6 & 7 & 8 & 9 & 10 & 11 & 12 & 13 & 14 \\
\hline \multicolumn{15}{|l|}{ Substrate utilization } \\
\hline Toluene $(0.5 \mathrm{mM})$ & + & - & - & + & NR & NR & + & $\mathrm{NR}$ & NR & NR & NR & NR & NR & - \\
\hline$p$-Cresol $(0.5 \mathrm{mM})$ & + & NR & - & + & NR & NR & $\mathrm{NR}$ & $\mathrm{NR}$ & NR & NR & NR & NR & NR & NR \\
\hline$m$-Cresol $(0.5 \mathrm{mM})$ & + & NR & NR & - & NR & NR & NR & NR & NR & NR & NR & NR & NR & $\mathrm{NR}$ \\
\hline Benzaldehyde (0.5 mM) & + & NR & - & + & NR & NR & NR & NR & NR & NR & NR & NR & NR & $\mathrm{NR}$ \\
\hline Pyruvate $(10 \mathrm{mM})$ & + & + & - & + & - & + & + & + & + & + & + & + & $\mathrm{NR}$ & + \\
\hline Butyrate $(10 \mathrm{mM})$ & + & + & - & + & - & NR & + & + & + & + & + & - & - & - \\
\hline Propionate $(10 \mathrm{mM})$ & + & + & - & + & - & + & + & $\mathrm{NR}$ & $\mathrm{NR}$ & + & + & - & - & - \\
\hline Fumarate $(10 \mathrm{mM})$ & - & + & NR & - & - & + & NR & $\mathrm{NR}$ & NR & NR & NR & NR & NR & $\mathrm{NR}$ \\
\hline Malate $(10 \mathrm{mM})$ & - & + & NR & - & + & + & NR & NR & NR & NR & + & + & NR & $\mathrm{NR}$ \\
\hline Lactate $(10 \mathrm{mM})$ & - & + & + & - & + UFE & $\mathrm{NR}$ & - & + & + & - & NR & + & + & - \\
\hline Motility & - & + & - & - & - & - & - & + & + & - & - & + & + & + \\
\hline \multicolumn{15}{|c|}{ Total lipid fatty acids (mol\%) } \\
\hline $15: 0$ anteiso & 4.6 & $0^{*}$ & $3.9^{*}$ & $\mathrm{NR}$ & NR & NR & $\mathrm{NR}$ & $\mathrm{NR}$ & NR & NR & $\operatorname{tr} \dagger$ & NR & $\operatorname{tr}$ & $\mathrm{NR}$ \\
\hline $18: 1 \omega 7 c$ & 0 & $0.8^{*}$ & $0.4^{*}$ & 3.7 & NR & NR & $\mathrm{NR}$ & $\mathrm{NR}$ & NR & NR & NR & NR & NR & NR \\
\hline
\end{tabular}

${ }^{*}$ Data for the type strain from this study.

$\dagger$ Data from Shelobolina et al. (2008). 
Motile, slightly curved rods, $2.3-4.0 \mu \mathrm{m}$ long and $0.5 \mu \mathrm{m}$ wide. Strictly anaerobic, Gram-stain-positive, spore-forming organism that oxidizes acetate totally to $\mathrm{CO}_{2}$. Utilizes ferrihydrite and ferric citrate as electron acceptors with acetate as electron donor and ferrihydrite, ferric citrate, sulfite and thiosulfate with pyruvate as electron donor. Does not reduce sulfate or sulfur. Ferments pyruvate but does not grow with hydrogen or with butyrate, propionate, lactate, succinate, $m$-cresol or $o$-cresol as electron donors. Electron donors used include toluene, $o$-xylene, benzyl

Table 2. Characteristics useful for differentiating strain UKTL ${ }^{\top}$ from related species of the genera Desulfitobacterium and Desulfosporosinus

Taxa: 1, strain $\mathrm{UKTL}^{\mathrm{T}}$ (data from this study); 2, Desulfitobacterium chlororespirans (Sanford et al., 1996); 3, Desulfitobacterium dehalogenans (Spring \& Rosenzweig, 2006); 4, Desulfitobacterium metallireducens (Spring \& Rosenzweig, 2006); 5, Desulfitobacterium hafniense (Spring \& Rosenzweig, 2006); 6, Desulfosporosinus orientis (Devereux et al., 1989; Stackebrandt et al., 1997). Unless indicated, data were determined in the studies listed above using identical methods. +, Utilized; -, not utilized; NR, not reported in the original literature; $d$, different reaction among strains. Characteristics in bold differentiate strain $\mathrm{TMJ}_{1}^{\mathrm{T}}$ from all other tested species of the genera Desulfitobacterium and Desulfosporosinus.

\begin{tabular}{|c|c|c|c|c|c|c|}
\hline Characteristic & 1 & 2 & 3 & 4 & 5 & 6 \\
\hline \multicolumn{7}{|l|}{ Substrate utilization } \\
\hline Hydrogen & - & + & + & - & - & + \\
\hline Acetate $(10 \mathrm{mM})$ & + & - & - & - & - & - \\
\hline Butyrate (10 mM) & - & + & + & + & d & + \\
\hline Fumarate $(10 \mathrm{mM})$ & + & - & NR & NR & NR & + \\
\hline Malate (10 mM) & + & NR & NR & NR & $\mathrm{NR}$ & - \\
\hline Succinate $(10 \mathrm{mM})$ & + & - & NR & NR & d & - \\
\hline Lactate $(10 \mathrm{mM})$ & - & + & + & + & + & + \\
\hline Ethanol $(5 \mathrm{mM})$ & - & NR & + & + & NR & + \\
\hline Methanol (5 mM) & - & NR & NR & NR & NR & + \\
\hline \multicolumn{7}{|l|}{ Electron acceptors used } \\
\hline $\mathrm{Fe}(\mathrm{III})(50 \mathrm{mM})$ & + & NR & NR & NR & $\mathrm{NR}$ & - \\
\hline $\mathrm{Fe}(\mathrm{III})$ citrate $(50 \mathrm{mM})$ & + & NR & NR & + & NR & - \\
\hline $\operatorname{Mn}(\mathrm{IV})(10 \mathrm{mM})$ & - & NR & NR & + & NR & - \\
\hline Sulfite (5 mM) & $+^{*}$ & + & + & - & + & + \\
\hline Sulfur $\left(1 \mathrm{~g} \mathrm{l}^{-1}\right)$ & - & + & + & + & + & + \\
\hline Nitrate $(10 \mathrm{mM})$ & - & - & + & - & - & - \\
\hline Fumarate $(40 \mathrm{mM})$ & - & - & + & - & - & + \\
\hline \multicolumn{7}{|l|}{$\begin{array}{l}\text { Total lipid fatty acids } \\
(\mathrm{mol} \%)\end{array}$} \\
\hline $15: 0$ iso & 1.9 & $0 \dagger$ & - & + & - & $0 \dagger$ \\
\hline $18: 1 \omega 7 c$ & 0 & $7.1 \dagger$ & NR & NR & NR & $1.4 \dagger$ \\
\hline Motility & + & $+\dagger$ & + & - & $\mathrm{d}$ & $+\dagger$ \\
\hline Spores $\ddagger$ & $\mathrm{E}, \mathrm{T}$ & $\mathrm{E}, \mathrm{T}$ & None & None & $\mathrm{E}, \mathrm{T}$ & $\mathrm{E}, \mathrm{ST}$ \\
\hline
\end{tabular}

${ }^{*}$ With sulfite as electron acceptor, strain $\mathrm{UKTL}^{\mathrm{T}}$ grew with pyruvate only as electron donor, not with acetate.

$\dagger$ Data for the type strain from this study.

‡E, Ellipsoidal; ST, subterminal; T, terminal. alcohol, benzaldehyde, phenol, $p$-cresol, acetate, fumarate, formate, succinate, malate and benzoate. Contains 15:0 iso but not $18: 1 \omega 7 c$ fatty acids. The major menaquinone is MK-7. The $\mathrm{pH}$ range for growth is $\mathrm{pH}$ 6.5-7.5 (optimum $\mathrm{pH}$ 6.6-7.0). Optimum growth temperature is $30{ }^{\circ} \mathrm{C}$. Characteristics that are useful to differentiate the type strain from other members of the genus Desulfitobacterium are depicted in Table 2. The $\mathrm{G}+\mathrm{C}$ content of the type strain is $47.7 \mathrm{~mol} \%$.

The type strain, $\mathrm{UKTL}^{\mathrm{T}}\left(=\mathrm{DSM} 19510^{\mathrm{T}}=\mathrm{JCM} 15765^{\mathrm{T}}\right)$, was isolated from soil of a former coal-gasification site in Gliwice, Poland.

\section{ACKNOWLEDGEMENTS}

The authors thank Bernhard Schink for stimulating discussions. Sabine Schäfer is acknowledged for assistance with gene sequencing. Helga Wehnes is thanked for electron microscopy and Angelika Wichmann for technical assistance with lipid analysis.

\section{REFERENCES}

Anderson, R. T. \& Lovley, D. R. (1999). Naphthalene and benzene degradation under $\mathrm{Fe}(\mathrm{III})$-reducing conditions in petroleum-contaminated aquifers. Bioremediat J 3, 121-135.

Anderson, R. T., Rooney-Varga, J. N., Gaw, C. V. \& Lovley, D. R. (1998). Anaerobic benzene oxidation in the Fe(III) reduction zone of petroleum-contaminated aquifers. Environ Sci Technol 32, 1222-1229.

Balashova, V. V. \& Zavarzin, G. A. (1979). Anaerobic reduction of ferric iron by hydrogen bacteria. Mikrobiologiia 48, 773-778 (in Russian).

Beller, H. R. \& Spormann, A. M. (1997). Anaerobic activation of toluene and $o$-xylene by addition to fumarate in denitrifying strain $\mathrm{T}$. J Bacteriol 179, 670-676.

Biegert, T., Fuchs, G. \& Heider, J. (1996). Evidence that anaerobic oxidation of toluene in the denitrifying bacterium Thauera aromatica is initiated by formation of benzylsuccinate from toluene and fumarate. Eur J Biochem 238, 661-668.

Bligh, E. G. \& Dyer, W. J. (1959). A rapid method of total lipid extraction and purification. Can J Biochem Physiol 37, 911-917.

Bond, D. R. \& Lovley, D. R. (2002). Reduction of Fe(III) oxide by methanogens in the presence and absence of extracellular quinones. Environ Microbiol 4, 115-124.

Caccavo, F., Jr, Lonergan, D. J., Lovley, D. R., Davis, M., Stolz, J. F. \& Mclnerney, M. J. (1994). Geobacter sulfurreducens sp. nov., a hydrogen- and acetate-oxidizing dissimilatory metal-reducing microorganism. Appl Environ Microbiol 60, 3752-3759.

Cashion, P., Holder-Franklin, M. A., McCully, J. \& Franklin, M. (1977). A rapid method for the base ratio determination of bacterial DNA. Anal Biochem 81, 461-466.

Chakraborty, R. \& Coates, J. D. (2004). Anaerobic degradation of monoaromatic hydrocarbons. Appl Microbiol Biotechnol 64, 437-446.

Christensen, T. H., Kjeldsen, P., Bjerg, P. L., Jensen, D. L., Christensen, J. B., Baun, A., Albrechtsen, H.-J. \& Heron, G. (2001). Biogeochemistry of landfill leachate plumes. Appl Geochem 16, 659718.

Cline, J. D. (1969). Spectrophotometric determination of hydrogen sulfide in natural waters. Limnol Oceanogr 14, 454-458. 
Coates, J. D., Ellis, D. J., Blunt-Harris, E. L., Gaw, C. V., Roden, E. E. \& Lovley, D. R. (1998). Recovery of humic-reducing bacteria from a diversity of environments. Appl Environ Microbiol 64, 15041509.

Coates, J. D., Bhupathiraju, V. K., Achenbach, L. A., Mclnerney, M. J. \& Lovley, D. R. (2001). Geobacter hydrogenophilus, Geobacter chapellei and Geobacter grbiciae, three new, strictly anaerobic, dissimilatory Fe(III)-reducers. Int J Syst Evol Microbiol 51, 581-588.

Coleman, M. L., Hedrick, D. B., Lovley, D. R., White, D. C. \& Pye, K. (1993). Reduction of $\mathrm{Fe}(\mathrm{III})$ in sediments by sulphate-reducing bacteria. Nature 361, 436-438.

Cummings, D. E., Snoeyenbos-West, O. L., Newby, D. T., Niggemyer, A. M., Lovley, D. R., Achenbach, L. A. \& Rosenzweig, R. F. (2003). Diversity of Geobacteraceae species inhabiting metal-polluted freshwater lake sediments ascertained by $16 \mathrm{~S}$ rDNA analyses. Microb Ecol 46, 257-269.

Curtis, P. D., Geyer, R., White, D. C. \& Shimkets, L. J. (2006). Novel lipids in Myxococcus xanthus and their role in chemotaxis. Environ Microbiol 8, 1935-1949.

Devereux, R., Delaney, M., Widdel, F. \& Stahl, D. A. (1989). Natural relationships among sulfate-reducing eubacteria. J Bacteriol 171, 6689-6695.

Geyer, R., Peacock, A. D., White, D. C., Cory, L. \& van Berkel, G. J. (2004). Atmospheric pressure chemical ionization and atmospheric pressure photoionization for simultaneous mass spectrophotometric analysis of microbial respiratory ubiquinones and menaquinones. J Mass Spectrom 39, 922-929.

Guckert, J. B., Antworth, C. P., Nichols, P. D. \& White, D. C. (1985) Phospholipid, ester-linked fatty acid profiles as reproducible assays for changes in prokaryotic community structure of estuarine sediments. FEMS Microbiol Lett 31, 147-158

Imachi, H., Sekiguchi, Y., Kamagata, Y., Hanada, S., Ohashi, A. \& Harada, H. (2002). Pelotomaculum thermopropionicum gen. nov., sp. nov., an anaerobic, thermophilic, syntrophic propionate-oxidizing bacterium. Int J Syst Evol Microbiol 52, 1729-1735.

Kostka, J. E., Dalton, D. D., Skelton, H., Dollhopf, S. \& Stucki, J. W. (2002). Growth of iron(III)-reducing bacteria on clay minerals as the sole electron acceptor and comparison of growth yields on a variety of oxidized iron forms. Appl Environ Microbiol 68, 6256-6262.

Kunapuli, U., Lueders, T. \& Meckenstock, R. U. (2007). The use of stable isotope probing to identify key iron-reducing microorganisms involved in anaerobic benzene degradation. ISME J 1, 643-653.

Leuthner, B., Leutwein, C., Schulz, H., Hörth, P., Haehnel, W., Schiltz, E., Schägger, H. \& Heider, J. (1998). Biochemical and genetic characterization of benzylsuccinate synthase from Thauera aromatica: a new glycyl radical enzyme catalysing the first step in anaerobic toluene metabolism. Mol Microbiol 28, 615-628.

Lin, B., Braster, M., van Breukelen, B. M., van Verseveld, H. W. Westerhoff, H. V. \& Röling, W. F. M. (2005). Geobacteraceae community composition is related to hydrochemistry and biodegradation in an iron-reducing aquifer polluted by a neighboring landfill. Appl Environ Microbiol 71, 5983-5991.

Liu, A., Garcia-Dominguez, E., Rhine, E. D. \& Young, L. Y. (2004). A novel arsenate respiring isolate that can utilize aromatic substrates. FEMS Microbiol Ecol 48, 323-332.

Lonergan, D. J., Jenter, H. L., Coates, J. D., Phillips, E. J. P., Schmidt, T. M. \& Lovley, D. R. (1996). Phylogenetic analysis of dissimilatory Fe(III)-reducing bacteria. J Bacteriol 178, 2402-2408.

Lovley, D. R. \& Anderson, R. T. (2000). Influence of dissimilatory metal reduction on fate of organic and metal contaminants in the subsurface. Hydrogeol J 8, 77-88.
Lovley, D. R. \& Phillips, E. J. P. (1986). Organic matter mineralization with reduction of ferric iron in anaerobic sediments. Appl Environ Microbiol 51, 683-689.

Lovley, D. R., Giovannoni, S. J., White, D. C., Champine, J. E., Phillips, E. J. P., Gorby, Y. A. \& Goodwin, S. (1993). Geobacter metallireducens gen. nov. sp. nov., a microorganism capable of coupling the complete oxidation of organic compounds to the reduction of iron and other metals. Arch Microbiol 159, 336-344.

Ludwig, W., Strunk, O., Westram, R., Richter, L., Meier, H., Yadhukumar, Buchner, A., Lai, T., Steppi, S. \& other authors (2004). ARB: a software environment for sequence data. Nucleic Acids Res 32, 1363-1371.

Lueders, T., Manefield, M. \& Friedrich, M. W. (2004). Enhanced sensitivity of DNA- and rRNA-based stable isotope probing by fractionation and quantitative analysis of isopycnic centrifugation gradients. Environ Microbiol 6, 73-78.

Mesbah, T., Premachandran, U. \& Whitman, W. (1989). Precise measurement of the $\mathrm{G}+\mathrm{C}$ content of deoxyribonucleic acid by highperformance liquid chromatography. Int J Syst Bacteriol 39, 159-167.

Morasch, B., Annweiler, E., Warthmann, R. J. \& Meckenstock, R. U. (2000). The use of a solid adsorber resin for enrichment of bacteria with toxic substrates and to identify metabolites: degradation of naphthalene, $o-$, and $m$-xylene by sulfate-reducing bacteria. J Microbiol Methods 44, 183-191.

Morasch, B., Schink, B., Tebbe, C. C. \& Meckenstock, R. U. (2004). Degradation of $o$-xylene and $m$-xylene by a novel sulfate-reducer belonging to the genus Desulfotomaculum. Arch Microbiol 181, 407417.

Nevin, K. P., Holmes, D. E., Woodard, T. L., Hinlein, E. S., Ostendorf, D. W. \& Lovley, D. R. (2005). Geobacter bemidjiensis sp. nov. and Geobacter psychrophilus sp. nov., two novel Fe(III)-reducing subsurface isolates. Int J Syst Evol Microbiol 55, 1667-1674.

Ramamoorthy, S., Sass, H., Langer, H., Schumann, P., Kroppenstedt, R. M., Spring, S., Overmann, J. \& Rosenzweig, R. F. (2006). Desulfosporosinus lacus sp. nov., a sulfate-reducing bacterium isolated from pristine freshwater lake sediments. Int J Syst Evol Microbiol 56, 2729-2736.

Roberts, J. L. (1947). Reduction of ferric hydroxide by strains of Bacillus polymyxa. Soil Sci 63, 135-140.

Robertson, W. J., Franzmann, P. D. \& Mee, B. J. (2000). Sporeforming, Desulfosporosinus-like sulphate-reducing bacteria from a shallow aquifer contaminated with gasoline. J Appl Microbiol 88, 248259.

Robertson, W. J., Bowman, J. P., Franzmann, P. D. \& Mee, B. J. (2001). Desulfosporosinus meridiei sp. nov., a spore-forming sulfatereducing bacterium isolated from gasolene-contaminated groundwater. Int J Syst Evol Microbiol 51, 133-140.

Rooney-Varga, J. N., Anderson, R. T., Fraga, J. L., Ringelberg, D. \& Lovley, D. R. (1999). Microbial communities associated with anaerobic benzene degradation in a petroleum-contaminated aquifer. Appl Environ Microbiol 65, 3056-3063.

Sanford, R. A., Cole, J. R., Löffler, F. E. \& Tiedje, J. M. (1996). Characterization of Desulfitobacterium chlororespirans sp. nov., which grows by coupling the oxidation of lactate to the reductive dechlorination of 3-chloro-4-hydroxybenzoate. Appl Environ Microbiol 62, 3800-3808

Shelobolina, E. S., Nevin, K. P., Blakeney-Hayward, J. D., Johnsen, C. V., Plaia, T. W., Krader, P., Woodard, T., Holmes, D. E., Gaw VanPraagh, C. \& Lovley, D. R. (2007). Geobacter pickeringii sp. nov., Geobacter argillaceus sp. nov. and Pelosinus fermentans gen. nov., sp. nov., isolated from subsurface kaolin lenses. Int J Syst Evol Microbiol 57, 126-135. 
Shelobolina, E. S., Vrionis, H. A., Findlay, R. H. \& Lovley, D. R. (2008). Geobacter uraniireducens sp. nov., isolated from subsurface sediment undergoing uranium bioremediation. Int J Syst Evol Microbiol 58, 1075-1078.

Spring, S. \& Rosenzweig, F. (2006). The genera Desulfitobacterium and Desulfosporosinus: taxonomy. In The Prokaryotes: a Handbook on the Biology of Bacteria, 3rd edn, vol. 4, pp. 771-786. Edited by M. Dworkin, S. Falkow, E. Rosenberg, K. H. Schleifer \& E. Stackebrandt. New York: Springer.

Stackebrandt, E., Sproer, C., Rainey, F. A., Burghardt, J., Päuker, O. \& Hippe, H. (1997). Phylogenetic analysis of the genus Desulfotomaculum: evidence for the misclassification of Desulfotomaculum guttoideum and description of Desulfotomaculum orientis as Desulfosporosinus orientis gen. nov., comb. nov. Int J Syst Bacteriol 47, 1134-1139.

Stackebrandt, E., Schumann, P., Schüler, E. \& Hippe, H. (2003). Reclassification of Desulfotomaculum auripigmentum as Desulfosporosinus auripigmenti corrig., comb. nov. Int J Syst Evol Microbiol 53, 1439-1443.

Stookey, L. L. (1970). Ferrozine - a new spectrophotometric reagent for iron. Anal Chem 42, 779-781.

Straub, K. L. \& Buchholz-Cleven, B. E. E. (2001). Geobacter bremensis sp. nov. and Geobacter pelophilus sp. nov., two dissimilatory ferriciron-reducing bacteria. Int J Syst Evol Microbiol 51, 1805-1808.

Straub, K. L. \& Schink, B. (2004). Ferrihydrite-dependent growth of Sulfurospirillum deleyianum through electron transfer via sulfur cycling. Appl Environ Microbiol 70, 5744-5749.

Straub, K. L., Hanzlik, M. \& Buchholz-Cleven, B. E. E. (1998). The use of biologically produced ferrihydrite for the isolation of novel ironreducing bacteria. Syst Appl Microbiol 21, 442-449.

Strimmer, K. \& von Haeseler, A. (1996). Quartet puzzling: a quartet maximum-likelihood method for reconstructing tree topologies. Mol Biol Evol 13, 964-969.

Sung, Y., Fletcher, K. E., Ritalahti, K. A., Apkarian, R. P., RamosHernández, N., Sanford, R. A., Mesbah, N. M. \& Löffler, F. E. (2006). Geobacter lovleyi sp. nov. strain SZ, a new metal-reducing and tetrachloroethene-dechlorinating bacterium. Appl Environ Microbiol 72, 2775-2782.

Tamaoka, J. \& Komagata, K. (1984). Determination of DNA base composition by reversed phase high-performance liquid chromatography. FEMS Microbiol Lett 25, 125-128.

Thamdrup, B. (2000). Bacterial manganese and iron reduction in aquatic sediments. Adv Microb Ecol 16, 61-84.

Villemur, R., Lanthier, M., Beaudet, R. \& Lépine, F. (2006). The Desulfitobacterium genus. FEMS Microbiol Rev 30, 706-733.

Weber, K. A., Achenbach, L. A. \& Coates, J. D. (2006). Microorganisms pumping iron: anaerobic microbial iron oxidation and reduction. Nat Rev Microbiol 4, 752-764.

Weisburg, W. G., Barns, S. M., Pelletier, D. A. \& Lane, D. J. (1991). $16 \mathrm{~S}$ ribosomal DNA amplification for phylogenetic study. J Bacteriol 173, 697-703.

White, D. C. \& Ringelberg, D. B. (1998). Signature lipid biomarker analysis. In Techniques in Microbial Ecology, pp. 255-272. Edited by R. S. Burlage, R. Atlas, D. Stahl, G. Geesey \& G. Sayler. New York: Oxford University Press.

Widdel, F. \& Bak, F. (1992). Gram-negative mesophilic sulfatereducing bacteria. In The Prokaryotes, 2nd edn, pp. 3352-3378. Edited by A. Balows, H. G. Trüper, M. Dworkin, W. Harder \& K. H. Schleifer. New York: Springer.

Winderl, C., Schaefer, S. \& Lueders, T. (2007). Detection of anaerobic toluene and hydrocarbon degraders in contaminated aquifers using benzylsuccinate synthase (bssA) genes as a functional marker. Environ Microbiol 9, 1035-1046.

Zamfirescu, D. \& Grathwohl, P. (2001). Occurrence and attenuation of specific organic compounds in the groundwater plume at a former gasworks site. J Contam Hydrol 53, 407-427.

Zavarzina, D. G., Sokolova, T. G., Tourova, T. P., Chernyh, N. A., Kostrikina, N. A. \& Bonch-Osmolovskaya, E. A. (2007). Thermincola ferriacetica sp. nov., a new anaerobic, thermophilic, facultatively chemolithoautotrophic bacterium capable of dissimilatory $\mathrm{Fe}$ (III) reduction. Extremophiles 11, 1-7. 